\title{
Analysis of genetic diversity of Hyptis pectinata (L.) Poit. plants using ISSR markers
}

\author{
R.B. Feitosa-Alcantara ${ }^{1}$, A.V.C. Silva ${ }^{2}$, A.F. Blank ${ }^{1}$, C.S. Almeida ${ }^{1}$, \\ S.V. Alvares-Carvalho ${ }^{1}$ and M.F. Arrigoni-Blank ${ }^{1}$ \\ ${ }^{1}$ Laboratório de Recursos Genéticos Vegetais e Óleos Essenciais, \\ Departamento de Engenharia Agronômica, \\ Universidade Federal de Sergipe, São Cristóvão, SE, Brasil \\ ${ }^{2}$ Laboratório de Biologia Molecular, \\ Embrapa Tabuleiros Costeiros, Aracaju, SE, Brasil \\ Corresponding author: M.F. Arrigoni-Blank \\ E-mail: fatima.blank@gmail.com
}

Genet. Mol. Res. 16 (3): gmr16039603

Received January 11, 2017

Accepted March 29, 2017

Published August 17, 2017

DOI http://dx.doi.org/10.4238/gmr16039603

Copyright (C) 2017 The Authors. This is an open-access article distributed under the terms of the Creative Commons Attribution ShareAlike (CC BY-SA) 4.0 License.

\begin{abstract}
Hyptis pectinata, popularly known as 'sambacaitá' or 'canudinho', is a medicinal and aromatic species widely used in the Brazilian Northeast. In Sergipe, the excessive extraction of natural resources may reduce the genetic variability of native plants. Thus, molecular markers have frequently been applied to the characterization of genetic diversity as the basis for germplasm conservation and breeding programs. The objective of the present study was to evaluate the genetic diversity of $H$. pectinata plants collected in different municipalities of the State of Sergipe using ISSR molecular markers. Thirty-four primers were tested, nine of which were selected for providing reproducible and analyzable amplification products, resulting in 67 polymorphic bands. The expected heterozygosity ranged from 0.32 to 0.45 , with a mean of 0.39 . Polymorphism information content was of 0.49 , which classifies the markers as moderately informative. A dendrogram was constructed
\end{abstract}

Genetics and Molecular Research 16 (3): gmr16039603 
using unweighted pair group method with arithmetic mean, forming three clusters: Cluster I (79 plants); Cluster II (4 plants); and Cluster III (2 plants). Jaccard's similarity coefficients ranged from 0.06 to 0.98 . The plants SAM-117 and SAM-119 presented greater similarity. Conversely, SAM-107 and SAM-171 were the most genetically distant. In general, H. pectinata plants collected in the State of Sergipe presented low to moderate genetic diversity.

Key words: Hyptis pectinata; Conservation strategies; Genetic diversity; ISSR

\section{INTRODUCTION}

Inadequate exploitation of environmental resources has had negative consequences, such as the fragmentation of ecosystems and the loss of genetic diversity. Several plant species influenced by this fragmentation are important sources of biologically active natural products, and the reduction of the genetic variability of these plants limits the scientific discovery of products of social and economic importance (Gonçalves et al., 2014).

Medicinal and aromatic species have been widely used by civilizations from the earliest days of humankind to the present day, either as the main treatment or as a complement for industrialized chemicals.

The medicinal and aromatic plant Hyptis pectinata (L.) Poit. (Lamiaceae) has antidematogenic, antinociceptive, antimicrobial, insecticide, anti-inflammatory, and leishmanicidal activities (Arrigoni-Blank et al., 2008; Nascimento et al., 2008; Silva et al., 2008; Raymundo et al., 2011; Falcao et al., 2013). A recent study on the toxicity of the essential oil of $H$. pectinata plants against leaf-cutting ants resulted in the deposit of a patent (Arrigoni-Blank et al., 2016). The confirmation of the formicidal potential of the essential oils of $H$. pectinata qualifies this species as a promising raw material source for the formulation and commercialization of bioproducts to control leaf-cutting ants. This finding, together with the unsystematic exploitation, the intervention of human activity, and the consequent deforestation of native areas highlight the importance to study and to create conservation strategies to maintain the diversity of this species.

The study of the wide variability in native plants is a fundamental way to conserve the species and select genes and alleles of interest for future use in breeding programs (Oliveira et al., 2013). Molecular markers have been the most frequent strategy used to analyze such variability. The inter-simple sequence repeat (ISSR) markers are advantageous owing to their high reproducibility and low costs; moreover, they do not require prior knowledge of DNA sequences for the development of specific primers of the species under analysis (Coral et al., 2016).

ISSR markers have been successfully used in the analysis of the genetic diversity of several species, such as Cunila menthoides Benth (Agostini et al., 2010), Mentha cervina (Rodrigues et al., 2013), Satureja bachtiarica Bunge (Khadivi-Khub et al., 2015), and Varronia curassavica Jacq. (Brito et al., 2016).

The present study was carried out to evaluate the genetic diversity of $H$. pectinata in Sergipe-Brazil, using ISSR molecular markers.

Genetics and Molecular Research 16 (3): gmr16039603 


\section{MATERIAL AND METHODS}

\section{Plant material and location}

Fresh and young leaves were collected from 86 native plants of $H$. pectinata in 17 municipalities in the State of Sergipe (Figure 1 and Table 1). Samples were wrapped in gauze and stored in ice to avoid oxidation. In the Laboratory of Molecular Biology of Embrapa Coastal Tablelands, they were stored in a freezer at $-80^{\circ} \mathrm{C}$ until DNA extraction.

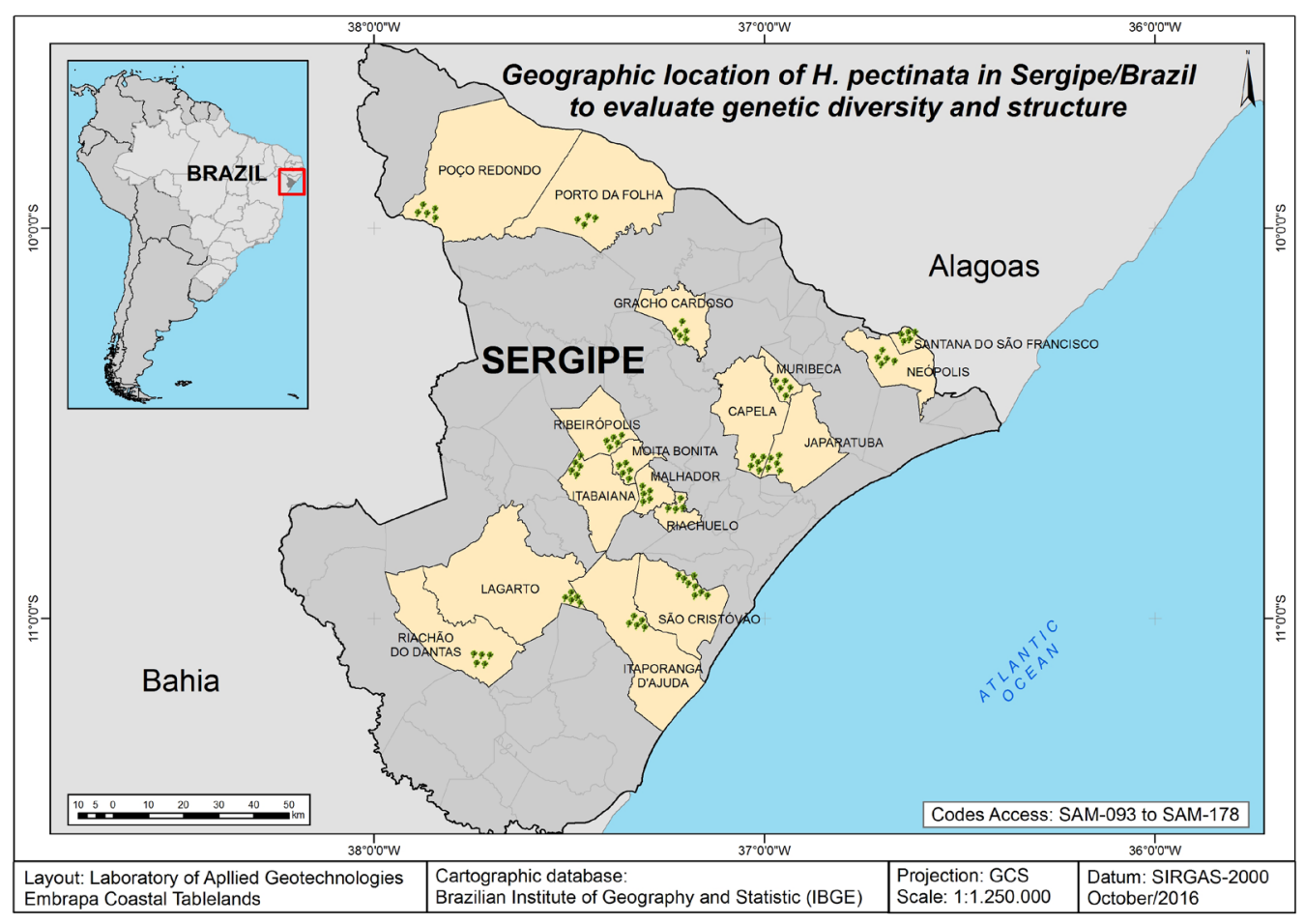

Figure 1. Location of collection points of 86 Hyptis pectinata plants in the State of Sergipe, Brazil.

\section{DNA extraction, quantification, and dilution}

Three young leaves were used for DNA extraction, following the procedures described by Doyle and Doyle (1990), modified as described by Alzate-Marin et al. (2005) to obtain DNA suitable for use in these experiments. The extracted DNA was quantified using the NanoDrop 2000c (Thermo Scientific, Wilmington, DE, USA). Samples used in the reactions were diluted $(5 \mathrm{ng} / \mathrm{mL})$ in TE buffer solution (10 mM Tris-HCl, $\mathrm{pH} 8.0,1 \mathrm{mM}$ EDTA) and stored in a freezer at $-20^{\circ} \mathrm{C}$.

\section{Polymerase chain reaction (PCR), electrophoresis, and photodocumentation}

Thirty-four ISSR primers were tested in this study (Eurofins MWG Operon - Operon 
Table 1. Identification of 86 Hyptis pectinata plants collected in the State of Sergipe, Brazil.

\begin{tabular}{|c|c|c|c|}
\hline Plant code & $\mathrm{N}$ & Location of origin & Geographical coordinates \\
\hline SAM093-SAM097 & 5 & Graccho Cardoso & $\begin{array}{l}10^{\circ} 17^{\prime} 10.7^{\prime \prime S ~} 37^{\circ} 16^{\prime} 57.2^{\prime \prime} \mathrm{W} ; 10^{\circ} 17^{\prime} 11.8^{\prime \prime S} 37^{\circ} 16^{\prime} 58.3^{\prime \prime} \mathrm{W} \\
10^{\circ} 17^{\prime} 12.3^{\prime \prime S ~} 37^{\circ} 16^{\prime} 58.4^{\prime \prime} \mathrm{W} ; 10^{\circ} 17^{\prime} 11.9^{\prime \prime} \mathrm{S} 37^{\circ} 16^{\prime} 59.2^{\prime \prime} \mathrm{W} \\
10^{\circ} 14^{\prime} 28.2^{\prime \prime S} 37^{\circ} 12^{\prime} 42.8^{\prime \prime} \mathrm{W}\end{array}$ \\
\hline SAM098-SAM102 & 5 & Japaratuba & $\begin{array}{l}10^{\circ} 35^{\prime} 00.8^{\prime \prime S} 36^{\circ} 57^{\prime} 51.7^{\prime \prime} \mathrm{W} ; 10^{\circ} 35^{\prime} 01.6^{\prime \prime S} 36^{\circ} 57^{\prime} 50.3^{\prime \prime} \mathrm{W} \\
10^{\circ} 35^{\prime} 01.2^{\prime \prime S} 36^{\circ} 57^{\prime} 49.8^{\prime \prime} \mathrm{W} ; 10^{\circ} 35^{\prime} 01.7^{\prime \prime} \mathrm{S} 36^{\circ} 57^{\prime} 50.0^{\prime \prime} \mathrm{W} \\
10^{\circ} 35^{\prime} 02.0^{\prime \prime} \mathrm{S} 36^{\circ} 57^{\prime} 49.3^{\prime \prime} \mathrm{W}\end{array}$ \\
\hline SAM103-SAM110 & 8 & São Cristóvão & $\begin{array}{l}10^{\circ} 54^{\prime} 44.1^{\prime \prime S} 37^{\circ} 11^{\prime} 46.1^{\prime \prime} \mathrm{W} ; 0^{\circ} 54^{\prime} 44.4^{\prime \prime S} 37^{\circ} 11^{\prime} 46.6^{\prime \prime} \mathrm{W} \\
10^{\circ} 54^{\prime} 43.8^{\prime \prime} \mathrm{S} 37^{\circ} 11^{\prime} 47.7^{\prime \prime} \mathrm{W} ; 0^{\circ} 53^{\prime} 33.4^{\prime \prime} \mathrm{S} 37^{\circ} 10^{\prime} 50.9^{\prime \prime} \mathrm{W} \\
10^{\circ} 53^{\prime} 32.9^{\prime \prime S} 37^{\circ} 10^{\prime} 52.3^{\prime \prime} \mathrm{W} ; 0^{\circ} 53^{\prime} 34.1^{\prime \prime S ~} 37^{\circ} 10^{\prime} 53.6^{\prime \prime} \mathrm{W} \\
10^{\circ} 53^{\prime} 34.1^{\prime \prime S} 37^{\circ} 10^{\prime} 53.7^{\prime \prime} \mathrm{W} ; 0^{\circ} 53^{\prime} 33.8^{\prime \prime S} 37^{\circ} 10^{\prime} 53.6^{\prime \prime} \mathrm{W}\end{array}$ \\
\hline SAM111-SAM114 & 4 & Porto da Folha & $\begin{array}{l}09^{\circ} 58^{\prime} 11.2^{\prime \prime S} 37^{\circ} 27^{\prime} 12.0^{\prime \prime} \mathrm{W} ; 09^{\circ} 58^{\prime} 11.0^{\prime \prime S} 37^{\circ} 27^{\prime} 12.1^{\prime \prime} \mathrm{W} \\
09^{\circ} 58^{\prime} 11.3^{\prime \prime S} 37^{\circ} 27^{\prime} 12.2^{\prime \prime} \mathrm{W} ; 09^{\circ} 58^{\prime} 11.4^{\prime \prime S ~} 37^{\circ} 27^{\prime} 12.3^{\prime \prime} \mathrm{W}\end{array}$ \\
\hline SAM115-SAM119 & 5 & Poço Redondo & $\begin{array}{l}09^{\circ} 57^{\prime} 45.2^{\prime \prime S} 37^{\circ} 51^{\prime} 51.2^{\prime \prime} \mathrm{W} ; 09^{\circ} 57^{\prime} 47.7^{\prime \prime S} 37^{\circ} 51^{\prime} 50.8^{\prime \prime} \mathrm{W} \\
09^{\circ} 57^{\prime} 48.1^{\prime \prime S} 37^{\circ} 51^{\prime} 53.7^{\prime \prime} \mathrm{W} ; 09^{\circ} 57^{\prime} 46.0^{\circ} \mathrm{S} 37^{\circ} 51^{\prime} 53.3^{\prime \prime} \mathrm{W} \\
09^{\circ} 57^{\prime} 48.7^{\prime \prime S} 37^{\circ} 51^{\prime} 53.5^{\prime \prime} \mathrm{W}\end{array}$ \\
\hline SAM120-SAM124 & 5 & Capela & $\begin{array}{l}10^{\circ} 35^{\prime} 29.8^{\prime \prime S ~} 36^{\circ} 59^{\prime} 08.5^{\prime \prime} \mathrm{W} ; 10^{\circ} 35^{\prime} 30.0^{\prime \prime S} 36^{\circ} 59^{\prime} 08.3^{\prime \prime} \mathrm{W} \\
10^{\circ} 35^{\prime} 30.1^{\prime \prime S ~} 36^{\circ} 59^{\prime} 07.7^{\prime \prime} \mathrm{W} ; 10^{\circ} 35^{\prime} 30.0^{\prime \prime} \mathrm{S} 36^{\circ} 59^{\prime} 08.5^{\prime \prime} \mathrm{W} \\
10^{\circ} 35^{\prime} 29.9^{\prime \prime S} 36^{\circ} 59^{\prime} 09.1^{\prime \prime} \mathrm{W}\end{array}$ \\
\hline SAM125-SAM129 & 5 & Muribeca & $\begin{array}{l}10^{\circ} 24^{\prime} 34.6^{\prime \prime S} 36^{\circ} 57^{\prime} 27.2^{\prime \prime} \mathrm{W} ; 10^{\circ} 24^{\prime} 34.8^{\prime \prime S} 36^{\circ} 57^{\prime} 27.3^{\prime \prime} \mathrm{W} \\
10^{\circ} 24^{\prime} 32.9^{\prime \prime S ~} 36^{\circ} 57^{\prime} 26.4^{\prime \prime} \mathrm{W} ; 10^{\circ} 24^{\prime} 32.5^{\prime \prime S ~} 36^{\circ} 57^{\prime} 26.3^{\prime \prime} \mathrm{W} \\
10^{\circ} 24^{\prime} 32.4^{\prime \prime S} 36^{\circ} 57^{\prime} 26.5^{\prime \prime} \mathrm{W}\end{array}$ \\
\hline SAM130-SAM134 & 5 & Santana do São Francisco & $\begin{array}{l}10^{\circ} 16^{\prime} 04.8^{\prime \prime} \mathrm{S} 36^{\circ} 36^{\prime} 53.0^{\prime \prime} \mathrm{W} ; 10^{\circ} 16^{\prime} 04.8^{\prime \prime} \mathrm{S} 36^{\circ} 36^{\prime} 53.3^{\prime \prime} \mathrm{W} \\
10^{\circ} 16^{\prime} 04.5^{\prime \prime S} 36^{\circ} 36^{\prime} 53.4^{\prime \prime} \mathrm{W} ; 10^{\circ} 16^{\prime} 03.4^{\prime \prime} \mathrm{S} 36^{\circ} 36^{\prime} 54.5^{\prime \prime} \mathrm{W} \\
10^{\circ} 16^{\prime} 04.6^{\prime \prime} \mathrm{S} 36^{\circ} 36^{\prime} 55.5^{\prime \prime} \mathrm{W}\end{array}$ \\
\hline SAM135-SAM139 & 5 & Neópolis & $\begin{array}{l}10^{\circ} 20^{\prime} 11.3^{\prime \prime} \mathrm{S} 36^{\circ} 41^{\prime} 16.5^{\prime \prime} \mathrm{W} ; 10^{\circ} 20^{\prime} 11.5^{\prime \prime S} 36^{\circ} 41^{\prime} 16.7^{\prime \prime} \mathrm{W} \\
10^{\circ} 20^{\prime} 11.2^{\prime \prime S} 36^{\circ} 41^{\prime} 16.9^{\prime \prime} \mathrm{W} ; 10^{\circ} 20^{\prime} 12.3^{\prime \prime} \mathrm{S} 36^{\circ} 41^{\prime} 18.1^{\prime \prime} \\
10^{\circ} 20^{\prime} 13.7^{\prime \prime} \mathrm{S} 36^{\circ} 41^{\prime} 20.2^{\prime \prime} \mathrm{W}\end{array}$ \\
\hline SAM140-SAM-143 & 4 & Riachuelo & $\begin{array}{l}10^{\circ} 43^{\prime} 04.8^{\prime \prime S} 37^{\circ} 12^{\prime} 41.6^{\prime \prime} \mathrm{W} ; 10^{\circ} 43^{\prime} 04.7^{\prime \prime S} 37^{\circ} 12^{\prime} 40.7^{\prime \prime} \mathrm{W} \\
10^{\circ} 43^{\prime} 04.6^{\prime \prime S ~} 37^{\circ} 12^{\prime} 39.5^{\prime \prime} \mathrm{W} ; 10^{\circ} 43^{\prime} 03.7^{\prime \prime} \mathrm{S} 37^{\circ} 12^{\prime} 39.1^{\prime \prime} \mathrm{W}\end{array}$ \\
\hline SAM144-SAM148 & 5 & Malhador & $\begin{array}{l}10^{\circ} 39^{\prime} 40.1^{\prime \prime S} 37^{\circ} 18^{\prime} 44.1^{\prime \prime W} ; 10^{\circ} 39^{\prime} 39.9^{\prime \prime S} 37^{\circ} 18^{\prime} 44.1^{\prime \prime} \mathrm{W} \\
10^{\circ} 39^{\prime} 39.8^{\prime \prime S ~} 37^{\circ} 18^{\prime} 44.2^{\prime \prime} \mathrm{W} ; 10^{\circ} 39^{\prime} 39.9^{\prime \prime} \mathrm{S} 37^{\circ} 18^{\prime} 44.1^{\prime \prime} \mathrm{W} \\
10^{\circ} 39^{\prime} 40.3^{\prime \prime S ~} 37^{\circ} 18^{\prime} 43.5^{\prime \prime} \mathrm{W}\end{array}$ \\
\hline SAM149-SAM153 & 5 & Moita Bonita & $\begin{array}{l}10^{\circ} 37^{\prime} 47.2^{\prime \prime S} 37^{\circ} 21^{\prime} 48.2^{\prime \prime} \mathrm{W} ; 10^{\circ} 37^{\prime} 47.3^{\prime \prime S} 37^{\circ} 21^{\prime} 47.8^{\prime \prime} \mathrm{W} \\
10^{\circ} 37^{\prime} 47.3^{\prime \prime S ~} 37^{\circ} 21^{\prime} 47.6^{\prime \prime} \mathrm{W} ; 10^{\circ} 37^{\prime} 47.7^{\prime \prime} \mathrm{S} 37^{\circ} 21^{\prime} 47.8^{\prime \prime} \mathrm{W} \\
10^{\circ} 37^{\prime} 47.4^{\prime \prime S} 37^{\circ} 21^{\prime} 47.6^{\prime \prime} \mathrm{W}\end{array}$ \\
\hline SAM154-SAM158 & 5 & Ribeirópolis & $\begin{array}{l}10^{\circ} 33^{\prime} 34.1^{\prime \prime S} 37^{\circ} 22^{\prime} 23.7^{\prime \prime} \mathrm{W} ; 10^{\circ} 33^{\prime} 32.8^{\prime \prime S} 37^{\circ} 22^{\prime} 23.5^{\prime \prime} \mathrm{W} \\
10^{\circ} 33^{\prime} 32.9^{\prime \prime S ~} 37^{\circ} 22^{\prime} 23.6^{\prime \prime} \mathrm{W} ; 10^{\circ} 33^{\prime} 33.5^{\prime \prime} \mathrm{S} 37^{\circ} 22^{\prime} 24.4^{\prime \prime} \mathrm{W} \\
10^{\circ} 33^{\prime} 33.7^{\prime \prime S} 37^{\circ} 22^{\prime} 24.5^{\prime \prime} \mathrm{W}\end{array}$ \\
\hline SAM159-SAM163 & 5 & Itabaiana & $\begin{array}{l}10^{\circ} 35^{\prime} 06.6^{\prime \prime S} 37^{\circ} 28^{\prime} 21.4^{\prime \prime} \mathrm{W} ; 10^{\circ} 35^{\prime} 05.3^{\prime \prime S} 37^{\circ} 28^{\prime} 20.9^{\prime \prime} \mathrm{W} \\
10^{\circ} 35^{\prime} 05.1^{\prime \prime S} 37^{\circ} 28^{\prime} 20.7^{\prime \prime} \mathrm{W} ; 10^{\circ} 35^{\prime} 04.9^{\prime \prime} \mathrm{S} 37^{\circ} 28^{\prime} 20.8^{\prime \prime} \mathrm{W} \\
10^{\circ} 35^{\prime} 04.7^{\prime \prime S} 37^{\circ} 28^{\prime} 20.9^{\prime \prime} \mathrm{W}\end{array}$ \\
\hline SAM164-SAM168 & 5 & Itaporanga d'Ajuda & $\begin{array}{l}10^{\circ} 59^{\prime} 44.8^{\prime \prime S} 37^{\circ} 20^{\prime} 04.2^{\prime \prime} \mathrm{W} ; 10^{\circ} 59^{\prime} 44.9^{\prime \prime} \mathrm{S} 37^{\circ} 20^{\prime} 04.3^{\prime \prime} \mathrm{W} \\
10^{\circ} 59^{\prime} 45.5^{\prime \prime S} 37^{\circ} 20^{\prime} 04.4^{\prime \prime} \mathrm{W} ; 10^{\circ} 59^{\prime} 45.0^{\prime \prime} \mathrm{S} 37^{\circ} 20^{\prime} 05.0^{\prime \prime} \mathrm{W} \\
10^{\circ} 59^{\prime} 45.2^{\prime \prime} \mathrm{S} 37^{\circ} 20^{\prime} 05.3^{\prime \prime} \mathrm{W}\end{array}$ \\
\hline SAM169-SAM173 & 5 & Lagarto & $\begin{array}{l}10^{\circ} 58^{\prime} 19.5^{\prime \prime S} 37^{\circ} 24^{\prime} 44.1^{\prime \prime} \mathrm{W} ; 10^{\circ} 58^{\prime} 19.3^{\prime \prime S ~} 37^{\circ} 24^{\prime} 44.2^{\prime \prime} \mathrm{W} \\
10^{\circ} 58^{\prime} 19.6^{\prime \prime S} 37^{\circ} 24^{\prime} 44.3^{\prime \prime} \mathrm{W} ; 10^{\circ} 58^{\prime} 20.7^{\prime \prime} \mathrm{S} 37^{\circ} 24^{\prime} 43.7^{\prime \prime} \mathrm{W} \\
10^{\circ} 58^{\prime} 20.9^{\prime \prime S} 37^{\circ} 24^{\prime} 44.6^{\prime \prime} \mathrm{W}\end{array}$ \\
\hline SAM174-SAM178 & 5 & Riachão do Dantas & $\begin{array}{l}11^{\circ} 05^{\prime} 46.8^{\prime \prime S} 37^{\circ} 43^{\prime} 28.5^{\prime \prime} \mathrm{W} ; 11^{\circ} 05^{\prime} 46.2^{\prime \prime S} 37^{\circ} 43^{\prime} 28.6^{\prime \prime} \mathrm{W} \\
11^{\circ} 05^{\prime} 45.5^{\prime \prime S ~} 37^{\circ} 43^{\prime} 28.5^{\prime \prime} \mathrm{W} ; 11^{\circ} 05^{\prime} 44.8^{\prime \prime} \mathrm{S} 37^{\circ} 43^{\prime} 28.8^{\prime \prime} \mathrm{W} \\
11^{\circ} 05^{\prime} 43.6^{\prime \prime S} 37^{\circ} 43^{\prime} 29.9^{\prime \prime} \mathrm{W}\end{array}$ \\
\hline
\end{tabular}

$\mathrm{N}=$ number of plants.

Technologies, Louisville, KY, USA; IDT - Integrated DNA Technologies, Coralville, IA, USA; Invitrogen - Thermo Fisher Scientific, Carlsbad, CA, USA) on 2\% agarose gel. PCRs were carried out in a total volume of $12 \mu \mathrm{L}$, containing $1 \mu \mathrm{L}$ genomic DNA $(5 \mathrm{ng} / \mu \mathrm{L}), 2.0 \mu \mathrm{L}$ primer (25.0 pmol), $5.4 \mu \mathrm{L}$ sterile MilQ water, $2 \mu \mathrm{L} \mathrm{10X} \mathrm{buffer} \mathrm{(100} \mathrm{mM} \mathrm{Tris-HCl,} \mathrm{pH} 8.5$, and 500 $\mathrm{mM} \mathrm{KCl}$ ) (Ludwig Biotec, Alvorada, RS, Brazil), $0.8 \mu \mathrm{L} \mathrm{MgCl}_{2}$ (50 Mm) (Ludwig Biotec), $0.6 \mu \mathrm{L}$ dNTP $5 \mathrm{nM}$ ), $0.2 \mu \mathrm{L}$ Taq polymerase $(5 \mathrm{U} / \mu \mathrm{L}$ ) (Ludwig Biotec). The material was then amplified in a Proflex thermocycler (Thermo Fisher Scientific, Applied Biosystems, Foster City, CA, USA), programmed with the following protocol: initial denaturation at $94^{\circ} \mathrm{C}$ for $5 \mathrm{~min}$, followed by 35 amplification cycles; denaturation at $94^{\circ} \mathrm{C}$ for $40 \mathrm{~s}$; primer annealing for $1 \mathrm{~min}$; extension at $72^{\circ} \mathrm{C}$, for $1 \mathrm{~min}$; and a final extension at $72^{\circ} \mathrm{C}$ for $7 \mathrm{~min}$, followed by cooling at $4^{\circ} \mathrm{C}$.

Genetics and Molecular Research 16 (3): gmr16039603 
Amplification products were subjected to electrophoresis on 2\% agarose gel. Molecular weights were estimated using 100-bp molecular weight marker (Ludwig) for each primer.

After electrophoresis, the gel was immersed in ethidium bromide solution for about 40 min and photodocumented with a Gel doc L-pix HE (Loccus Biotecnologia, Brazil).

\section{Data analysis}

For the analyses, a binary matrix was constructed, according to the absence $(0)$ or presence (1) of fragments, from the visualization of the bands on the gels.

Correlation estimates and the stress value were calculated using the Genes software (Cruz, 2006) for the analysis of fragment optimization.

Genetic diversity parameters, such as expected heterozygosity $\left(H_{\mathrm{E}}\right)$, polymorphism information content (PIC), and Shannon index were calculated using the GENALEX 6.5 software (Peakall and Smouse, 2012).

The Jaccard's similarity coefficient (Jaccard, 1908) was calculated, and a dendrogram was constructed by the unweighted pair group method with arithmetic mean (UPGMA), using the NTSYSpc 2.0 software (Rohlf, 2001).

\section{RESULTS}

A high level of polymorphism (100\%) was found in ISSR markers among H. pectinata plants from the State of Sergipe. Fragments were visualized by the images generated by photodocumentation of the agarose gels (Figure 2).

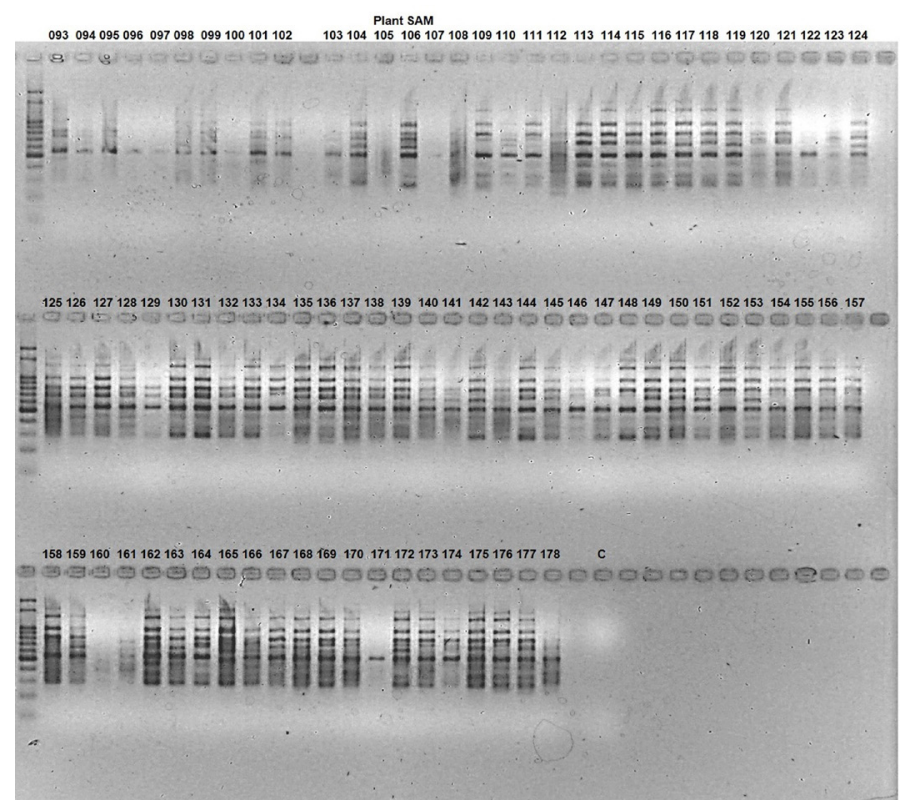

Figure 2. Agarose gel showing the electrophoretic profile of the inter-simple sequence repeat marker amplified using the primer UBC 807 for 86 Hyptis pectinata plants collected in different municipalities of the State of Sergipe, Brazil. C: negative control.

Genetics and Molecular Research 16 (3): gmr16039603 
Of the 34 primers tested, nine provided reproducible and analyzable amplification products, totaling 67 fully polymorphic fragments, ranging from 4 (UBC 888) to 10 (UBC 861 ), and a mean number of 7.45 bands per primer (Table 2).

Table 2. Annealing temperature, Sequence, and amplified products used to analyze genetic diversity in Hyptis pectinata plants collected in the State of Sergipe, Brazil.

\begin{tabular}{l|l|c|c|c|c}
\hline Primer & Sequence $\left(5^{\prime}-3^{\prime}\right)$ & Length (bp) & Annealing temperature $\left({ }^{\circ} \mathrm{C}\right)$ & Total number of fragments & Polymorphism $(\%)$ \\
\hline UBC 807 & AGA GAG AGA GAG AGA GT & $100-1000$ & 47.0 & 9 & 100.0 \\
\hline UBC 809 & AGA GAG AGA GAG AGA GG & $100-750$ & 57.2 & 9 & 100.0 \\
\hline UBC 810 & GAG AGA GAG AGA GAG AT & $100-750$ & 54.8 & 8 & 100.0 \\
\hline UBC 835 & AGA GAG AGA GAG AGA GY & $100-750$ & 58.8 & 9 & 100.0 \\
\hline UBC 841 & GAG AGA GAG AGA GAG AYC & $100-750$ & 58.8 & 7 & 100.0 \\
\hline UBC 851 & GTG TGT GTG TGT GTG TYG & $150-1000$ & 49.2 & 6 & 100.0 \\
\hline UBC 861 & ACC ACC ACC ACC ACC ACC & $150-750$ & 64.5 & 5 & 100.0 \\
\hline UBC 862 & AGC AGC AGC AGC AGC AGC & $150-500$ & 64.5 & 4 & 100.0 \\
\hline UBC 888 & BDB CAC ACA CAC ACA CA & $150-300$ & 56.4 & & 100.0 \\
\hline
\end{tabular}

In native plants of $H$. pectinata, the Shannon index ranged from 0.48 to 0.64 , with a mean value of 0.58 per primer. For the $H_{\mathrm{E}}$, values ranged from 0.32 (UBC 862) to 0.45 (UBC 809), with mean values of 0.39 .

The Jaccard's similarity coefficient used to calculate the genetic similarity among the $86 \mathrm{H}$. pectinata plants by the ISSR markers ranged from 0.06 to 0.98 , with a mean value of 0.65 . SAM-117 and SAM-119, both from the Municipality of Poço Redondo, presented a greater similarity. Conversely, SAM-107 and SAM-171 were the most genetically distant. Most of the pairs with higher coefficients belonged to the same municipalities, and those with lower coefficients belonged to different municipalities. SAM-097 (Graccho Cardoso) presented, in general, the lowest similarity coefficient (Table 3).

Table 3. Pairs of plants with extreme values of the Jaccard's similarity coefficient.

\begin{tabular}{|c|c|c|c|}
\hline \multicolumn{2}{|c|}{ Greater similarity } & \multicolumn{2}{|c|}{ Lower similarity } \\
\hline Pairs & Coefficients & Pairs & Coefficients \\
\hline SAM-117 x SAM-119 & 0.9800 & SAM-107 x SAM-171 & 0.0600 \\
\hline SAM-113 x SAM-114 & 0.9622 & SAM-107 x SAM-161 & 0.1052 \\
\hline SAM-114 x SAM-115 & 0.9622 & SAM-097 x SAM-175 & 0.1206 \\
\hline SAM-115 x SAM-116 & 0.9615 & SAM-094 x SAM-160 & 0.1315 \\
\hline SAM-116 x SAM-119 & 0.9607 & SAM-100 x SAM-107 & 0.1363 \\
\hline SAM-120 x SAM-121 & 0.9565 & SAM-107 x SAM-160 & 0.1428 \\
\hline SAM-149 x SAM-150 & 0.9649 & SAM-097 x SAM-165 & 0.1428 \\
\hline SAM-154 x SAM-155 & 0.9655 & SAM-097 x SAM-165 & 0.1451 \\
\hline SAM-166 x SAM-167 & 0.9655 & SAM-097 x SAM-130 & 0.1500 \\
\hline SAM-176 x SAM-177 & 0.9666 & SAM-110 x SAM-160 & 0.1500 \\
\hline SAM-137 x SAM-138 & 0.9508 & SAM-101 x SAM-171 & 0.1522 \\
\hline SAM-133 x SAM-139 & 0.9500 & SAM-097 x SAM-152 & 0.1525 \\
\hline SAM-144 x SAM-145 & 0.9464 & SAM-160 x SAM-165 & 0.1525 \\
\hline SAM-163 x SAM-167 & 0.9491 & SAM-097 x SAM-166 & 0.1551 \\
\hline SAM-167 x SAM-168 & 0.9482 & SAM-097 x SAM-167 & 0.1552 \\
\hline SAM-172 x SAM-177 & 0.9508 & SAM-097 x SAM-149 & 0.1579 \\
\hline SAM-168 x SAM-170 & 0.9473 & SAM-097 x SAM-150 & 0.1579 \\
\hline SAM-126 x SAM-127 & 0.9444 & SAM-097 x SAM-154 & 0.1579 \\
\hline SAM-127 x SAM-128 & 0.9434 & SAM-097 x SAM-147 & 0.1632 \\
\hline SAM-137 x SAM-139 & 0.9344 & SAM-097 x SAM-113 & 0.1698 \\
\hline
\end{tabular}


The $86 \mathrm{H}$. pectinata plants were distributed into three groups based on the cluster analysis: Cluster I (79 plants); Cluster II (4 plants); Cluster III (2 plants) (Figure 3). SAM107 was not associated with any of the clusters, suggesting greater genetic diversity when compared with the other plants.

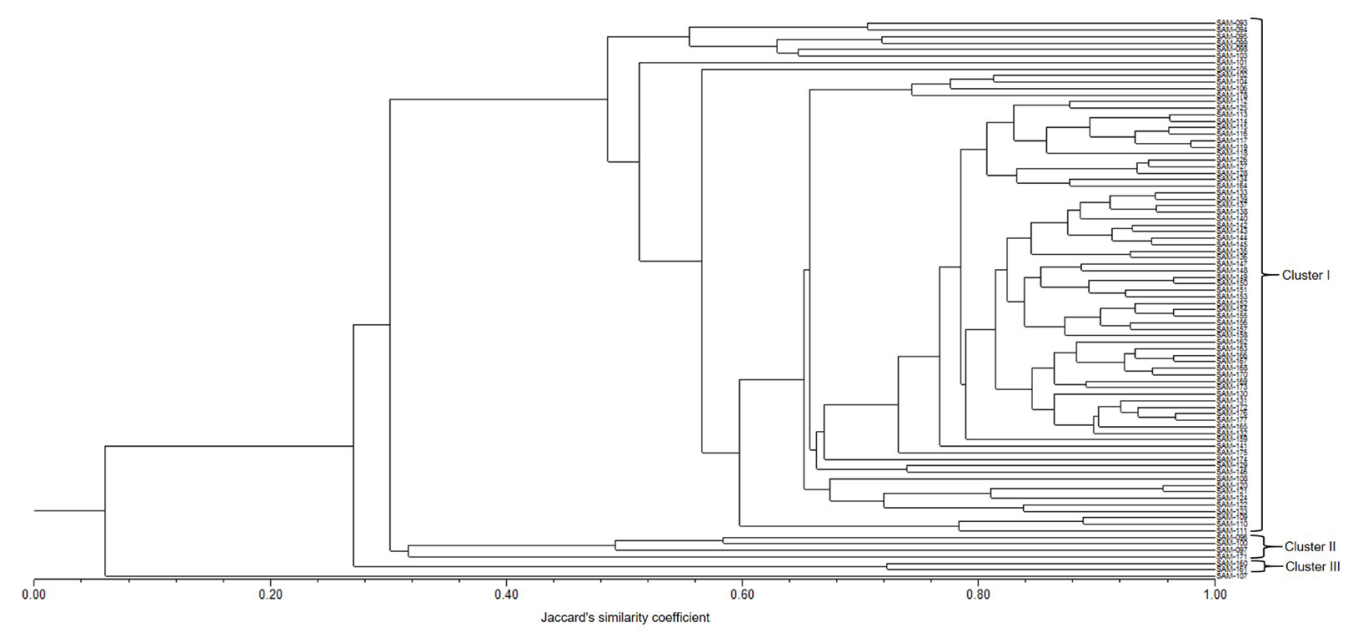

Figure 3. Dendrogram generated by the UPGMA analysis of the Jaccard's similarity coefficients for 86 Hyptis pectinata plants collected in different municipalities of the State of Sergipe, Brazil.

\section{DISCUSSION}

Despite the several studies with ISSR used in plants of the family Lamiaceae, this is the first report on the genetic diversity of the species $H$. pectinata, which presented low to moderate diversity among the plants evaluated in the State of Sergipe. Fracaro and Echeverrigaray (2006) observed high genetic diversity in a study with Hesperozygis ringens Benth. plants collected in different regions of the South of Brazil. Agostini et al. (2010), when studying Cunila menthoides Benth. plants, found low genetic variability. Gadidasu et al. (2011) used 15 primers in a study with Hyptis suaveolens, which amplified a total of 123 fragments, ranging from 7 to 12 fragments per primer. Khadivi-Khub et al. (2015) studied individuals of Satureja bachtiarica Bunge. and observed high genetic diversity among them.

ISSR molecular markers have also been used as efficient tools to analyze the genetic diversity of many other medicinal plant species. Pillai et al. (2012) observed that 15 primers amplified a total of 91 fragments in Rauvolfia serpentina L., ranging from 2 to 11 fragments per primer. Tripathi et al. (2012) studied 25 primers in Bacopa monnieri L. and observed a mean amplification of 11 fragments. Brito et al. (2016) analyzed the genetic diversity of Varronia curassavica accessions and observed that 14 primers resulted in a mean amplification of 11 fragments. Xing et al. (2016) observed the mean value of 6.9 fragments from 15 primers in a study with Toona sinensis Roem.

The Shannon index may range from 0 to 1 , with lower genetic diversity represented by values closer to zero (Silva et al., 2015). In the native plants of $H$. pectinata used in the present study, primers showed a mean value of 0.58 , which corresponds to moderate diversity.

Genetics and Molecular Research 16 (3): gmr16039603 
$H_{\mathrm{E}}$ showed a mean value of 0.39 , indicating low to moderate genetic variability among the studied plants.

PIC in the present study was of 0.49 . Since this parameter defines the efficiency of the molecular marker in revealing the polymorphism between plants (Botstein et al.,1980), the markers used in the present study are considered as moderately informative (PIC $>0.5$ highly informative; $0.25<$ PIC $<$ and 0.5 - moderately informative; and $\mathrm{PIC}<0.25$ - poorly informative).

According to the dendrogram, $91.9 \%$ of the evaluated plants formed a single cluster, being very similar genetically. Plants more geographically isolated and with difficult access exhibit greater genetic differentiation (Gois et al., 2014). Several random $H$. pectinata plants occur in locations of high and easy accessibility, such as road borders and backyards, where the flow of transport, people, and animals is constant. The seed of this species is quite light and small and can be easily transported to different locations, which may explain the similarity found among plants.

Some plants collected in the same municipality were clustered separately. Different evolutionary factors may influence these genetic differentiations, such as migration, mutation, and natural selection (Loveless and Hamrick, 1984).

Faced with the increasing devastation of plant areas and with the use of medicinal plants by the population, studies that address the analysis of genetic diversity are fundamental to select priority genotypes that may serve to guide future pharmacological studies (Gonçalves et al., 2014). Genetic diversity of plants of the same species can result in the production of several active compounds, and consequently in several biological properties since genetic factors can influence the synthesis of these compounds.

Molecular markers allow quantifying the diversity between individuals of the same species and clustering the genetically similar ones. Therefore, they are efficient and extremely appropriate tools for the elaboration of conservation strategies, as well as for the use of plant resources in future breeding programs.

The genetic diversity found among native plants of $H$. pectinata of the State of Sergipe can be considered as low to intermediate. These results are important to guide the choice of conservation strategies of this species and demonstrate the need to use a greater number of primers and plants of $H$. pectinata for a better evaluation of the genetic diversity.

\section{Conflicts of interest}

The authors declare no conflict of interest.

\section{ACKNOWLEDGMENTS}

The authors thank CNPq, FAPITEC/SE, CAPES, and Embrapa Tabuleiros Costeiros for their support of this study.

\section{REFERENCES}

Agostini G, Echeverrigaray S and Souza-Chies TT (2010). Genetic diversity of the endangered Brazilian endemic herb Cunila menthoides Benth. (Lamiaceae) and its implications for conservation. Biochem. Syst. Ecol. 38: 1111-1115. http://dx.doi.org/10.1016/j.bse.2010.12.001

Genetics and Molecular Research 16 (3): gmr16039603 
Alzate-Marin AL, Guidugli MC, Soriani HH and Mestriner MA (2005). Otimização de um método econômico e rápido de extração de DNA para quatro espécies de árvores tropicais. In: Anais do $51^{\circ}$ Congresso Brasileiro de Genética, Águas de Lindóia.

Arrigoni-Blank MF, Antoniolli AR, Caetano LC, Campos DA, et al. (2008). Antinociceptive activity of the volatile oils of Hyptis pectinata L. Poit. (Lamiaceae) genotypes. Phytomedicine 15: 334-339. http://dx.doi.org/10.1016/j. phymed.2007.09.009

Arrigoni-Blank MF, Alcantara-Feitosa RB, Blank AF, Bacci L, et al. (2016). Formulação formicida, método para controlar ou eliminar formigas cortadeiras à base de óleo essencial de genótipos de Hyptis pectinata, patente BR-10-201601015. Instituto Nacional da Propriedade Industrial, Rio de Janeiro.

Botstein D, White RL, Skolnick M and Davis RW (1980). Construction of a genetic linkage map in man using restriction fragment length polymorphisms. Am. J. Hum. Genet. 32: 314-331.

Brito FA, Nizio DAC, Silva AVC, Diniz LEC, et al. (2016). Genetic diversity analysis of Varronia curassavica Jacq. accessions using ISSR markers. Genet. Mol. Res. 15: 1-10. http://dx.doi.org/10.4238/gmr.15038681

Coral LLT, Cepková PH, Lojka B, Weber JC, et al. (2016). Genetic diversity in Guazuma crinita from eleven provenances in the Peruvian Amazon revealed by ISSR markers. Bosque (Valdivia) 37: 63-70. http://dx.doi.org/10.4067/S0717$\underline{92002016000100007}$

Cruz CD (2006). Programa Genes: análise multivariada e simulação. Editora UFV, Viçosa.

Doyle JJ and Doyle JL (1990). Isolation of plant DNA from fresh tissue. Focus 12: 13-15.

Falcao RA, do Nascimento PL, de Souza SA, da Silva TM, et al. (2013). Antileishmanial Phenylpropanoids from the Leaves of Hyptis pectinata (L.) Poit. Evid. Based Complement. Alternat. Med. 2013: 460613. http://dx.doi. org/10.1155/2013/460613

Fracaro F and Echeverrigaray S (2006). Genetic variability in Hesperozygis ringens Benth. (Lamiaceae), an endangered aromatic and medicinal plant of southern Brazil. Biochem. Genet. 44: 479-490. http://dx.doi.org/10.1007/s10528-006-9044-z

Gadidasu KK, Murthy EN, Nataraj P, Srinivas K, et al. (2011). ISSR markers reveal genetic polymorphism in two morphological variants of Hyptis suaveolens invasive to India. Med. Aromat. Plant Sci. Biotechnol. 5: 166-168.

Gois IB, Ferreira RA, Sila-Mann R, Pantaleão SM, et al. (2014). Variabilidade genética em populações naturais de Ziziphus joazeiro Mart., por meio de marcadores moleculares RAPD. Rev. Arvore 38: 621-630. http://dx.doi.org/10.1590/ $\underline{\text { S0100-67622014000400005 }}$

Gonçalves LO, Pinheiro JB, Zucchi MI and Silva-Mann R (2014). Caracterização genética de mulungu (Erythrina velutina Willd.) em áreas de baixa ocorrência. Rev. Cienc. Agron. 45: 290-298. http://dx.doi.org/10.1590/S1806$\underline{66902014000200009}$

Jaccard P (1908). Nouvelles recherches sur la distribution florale. Bull. Soc. Vaud. Sci. Nat. 44: 223-270.

Khadivi-Khub A, Salehi-Arjmand H, Movahedi K and Hadian J (2015). Molecular and morphological variability of Satureja bachtiarica in Iran. Plant Syst. Evol. 301: 77-93. http://dx.doi.org/10.1007/s00606-014-1055-3

Loveless MD and Hamrick JL (1984). Ecological determinants of genetic structure in plant populations. Annu. Rev. Ecol. Syst. 15: 65-95. http://dx.doi.org/10.1146/annurev.es.15.110184.000433

Nascimento PFC, Alviano WS, Nascimento ALC, Santos PO, et al. (2008). Hyptis pectinata essential oil: chemical composition and anti-Streptococcus mutans activity. Oral Dis. 14: 485-489. http://dx.doi.org/10.1111/j.1601$\underline{0825.2007 .01405 . \mathrm{x}}$

Oliveira EM, Junior WO, Oliveira J and Castro HG (2013). Genetic divergence among mentrasto accessions based on RAPD markers at Tocantins State. J. Biotec. Biodivers. 4: 290-298.

Peakall R and Smouse PE (2012). GenAlEx 6.5: genetic analysis in Excel. Population genetic software for teaching and research--an update. Bioinformatics 28: 2537-2539. http://dx.doi.org/10.1093/bioinformatics/bts460

Pillai PP, Sajan JS, Menon KM, Jayakumar KSP, et al. (2012). ISSR analysis reveals high intraspecific variation in Rauvolfia serpentina L. - A high value medicinal plant. Biochem. Syst. Ecol. 40: 192-197. http://dx.doi.org/10.1016/j. bse.2011.10.019

Raymundo LJRP, Guilhon CC, Alviano DS, Matheus ME, et al. (2011). Characterisation of the anti-inflammatory and antinociceptive activities of the Hyptis pectinata (L.) Poit essential oil. J. Ethnopharmacol. 134: 725-732. http:// dx.doi.org/10.1016/j.jep.2011.01.027

Rodrigues L, Van den Berg C, Póvoa O and Monteiro A (2013). Low genetic diversity and significant structuring in the endangered Mentha cervina populations and its implications for conservation. Biochem. Syst. Ecol. 50: 51-61. http:// dx.doi.org/10.1016/j.bse.2013.03.007

Rohlf FJ (2001). NTSYSpc: numerical taxonomy system, Version 2.0. Exeter Publishing, Setauket.

Silva AVC, Muniz EN, Almeida CS, Vitória MF, et al. (2015). Genetic diversity and sex identification in Genipa americana L. Trop. Subtrop. Agroecosys. 18: 81-86.

Genetics and Molecular Research 16 (3): gmr16039603 
Silva WJ, Dória GAA, Maia RT, Nunes RS, et al. (2008). Effects of essential oils on Aedes aegypti larvae: alternatives to environmentally safe insecticides. Bioresour. Technol. 99: 3251-3255. http://dx.doi.org/10.1016/j. biortech.2007.05.064

Tripathi N, Chouhan DS, Saini N and Tiwari S (2012). Assessment of genetic variations among highly endangered medicinal plant Bacopa monnieri (L.) from Central India using RAPD and ISSR analysis. 3 Biotech 2: 327-336.

Xing PY, Liu T, Song ZQ and Li XF (2016). Genetic diversity of Toona sinensis Roem in China revealed by ISSR and SRAP markers. Genet. Mol. Res. 15: 1-12. http://dx.doi.org/10.4238/gmr.15038387

Genetics and Molecular Research 16 (3): gmr16039603 